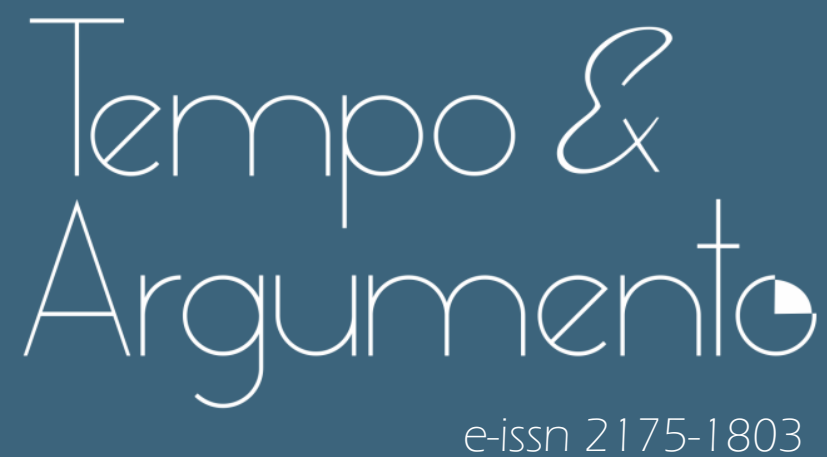

\title{
The Creation and Early Development of the Zimbabwe Defence Forces (ZDF) 1980-93
}

* Timothy Stapleton

Ph.D. of History by Dalhousie University.

Professor at the Department of History of the University of Calgary.

Calgary - CANADA

hist.ucalgary.ca/manageprofile/profiles/timothy-stapleton-cv

timothy.stapleton@ucalgary.ca

(D) orcid.org/0000-000 1-6759-5457

To cite this article (ABNT):

STAPLETON, Timothy. The Creation and Early Development of the Zimbabwe Defence Forces (ZDF) 1980-93. Tempo e Argumento, Florianópolis, v. 13, n. 32, e0104, jan./abr. 2021.

do) http://dx.doi.org/10.5965/2175180313322021e0104

Received on 22/10/2020 Approved on 05/03/2021 


\title{
The Creation and Early Development of the Zimbabwe Defence Forces (ZDF) $1980-93^{1}$
}

\begin{abstract}
Given the 2017 coup in Zimbabwe, a rare event in Southern Africa but sadly common in the rest of the continent, this paper discusses the beginnings of the politicization of the Zimbabwe Defence Forces (ZDF) during the 1980s. At the end of the country's war for independence in 1980, the ZDF formed as an amalgamation of former Rhodesian state military personnel and insurgents from the liberation movements of the Zimbabwe African People's Union (ZAPU) and the Zimbabwe African National Union (ZANU). Personnel from ZANU came to dominate Zimbabwe's new military given the lack of a specific agreement over the integration process, their numerical superiority, and ZANU's electoral success that gave it political power. During the ZDF integration exercise of the early 1980s, British advisors attempted to create a Western-style force but acted pragmatically while North Korean instructors helped create an overtly ZANU affiliated brigade and party militia. In addition, South African destabilization and the rapid departure of former Rhodesian officers gave way to the accelerated promotion of former insurgents mostly affiliated with the ZANU government. Lastly, the further ZANU-ization of the ZDF occurred within the context of operations in southwestern Zimbabwe where it eliminated ZAPU as an opposition political movement and committed atrocities, and in Mozambique where Zimbabwean troops cooperated with allies from overtly politicized armies of neighboring states.
\end{abstract}

Keywords: Zimbabwe. Military. Politicization. Integration. Liberation movements.

\section{A Criação e o Desenvolvimento Inicial das Forças de Defesa do Zimbábue (ZDF) 1980-93}

\begin{abstract}
Resumo
Em 2017 deu-se um Golpe de Estado no Zimbábue, um evento raro na parte sul de África, mas infelizmente comum no resto do continente. Este artigo aborda o início da politização das Forças de Defesa do Zimbábue (ZDF) durante os anos 1980. No final da guerra de independência em 1980, as ZDF formaram-se como uma amálgama de ex-militares da Rodésia e insurgentes dos movimentos de libertação da União do Povo Africano do Zimbábue (ZAPU) e da União Nacional Africano do Zimbábue (ZANU). Os militares da ZANU passaram a dominar as novas Forças Armadas do Zimbábue devido à falta de um acordo específico sobre o processo de integração, conseguindo pela superioridade numérica e o sucesso eleitoral da ZANU que lhe conferiu um poder político. Durante o exercício de integração da ZDF no início dos anos 1980, os conselheiros britânicos tentaram criar uma força de estilo ocidental, mas agiram pragmaticamente. Por outro lados instrutores norte-coreanos ajudaram a criar uma Brigada afiliada à ZANU funcionando como uma milícia do partido. Além disso, a desestabilização sul-africana e a rápida saída de ex-oficiais da Rodésia abriram espaço para a promoção acelerada de ex-insurgentes, na sua maioria filiados ao governo de ZANU. Por último, a maior "ZANUização" das ZDF ocorreram no contexto das operações no sudoeste do Zimbábue, onde eliminaram as forças da ZAPU como um movimento político de oposição e conduziu atrocidades. Tal como em Moçambique, onde as tropas do Zimbábue cooperaram como aliados de exércitos "politizados" de estados vizinhos.
\end{abstract}

Palavras-chave: Zimbábue. Militar. Politização. Integração. Movimentos de libertação. 


\section{Introduction}

In November 2017, troops of the Zimbabwe Defence Force (ZDF) took control of the state, replacing long-ruling President Robert Mugabe shortly after dismissing Emerson Mnangagwa as vice president. Although military coups and regimes were common in many parts of post-colonial Africa during the 1960s and 1970s, this represented the first such event in the history of Zimbabwe and one of very few coups in mainland Southern Africa (BAYNHAM, 1988; DECALO, 1976; SIOLLUN, 2009). In deciding the long-contested issue of who would succeed the elderly President Mugabe, and despite pronouncements from military officers that they had not really conducted a coup but instead a brief national celebration over what appeared to be the end of a dictatorship, the ZDF acted in contravention of Zimbabwe's constitution that had come into effect in 2013. According to that constitution, "The Defence Forces must respect the fundamental rights and freedoms of all persons and be non-partisan, national in character, patriotic, professional and subordinate to the civilian authority" (ZIMBABWE, 2013). By acting as "kingmaker" among rival leaders of the Zimbabwe African National Union - Patriotic Front (ZANU-PF), Zimbabwe's military officers, demonstrated their essential political character and deep involvement with the party that had governed the country since its independence in 1980.

Since the early 2000s, a series of public statements by ZDF senior officers betrayed their political loyalties and made the 2017 coup unsurprising. Before 2013, previous manifestations of the 1980 independence constitution did not include explicit language relating to the non-partisan nature of the armed forces, though at the same time Zimbabwe had never officially comprised a one-party state with an overtly politicized military like some of its neighbors. Strong public political statements by military officers became routine during Zimbabwe's political and economic crisis of the first decade of the 2000s when ZANU-PF faced its first major electoral challenge from the new Movement for Democratic Change (MDC). Most famously, in the weeks before the March 2002 presidential elections, ZDF chief Major General Vitalis Zvinavashe and Air Force of Zimbabwe (AFZ) Commander Air Marshal Perence Shiri announced that they would reject the election of a president who had not fought, as they had, in the country's 
liberation war against white minority rule during the late 1960s and 1970s (QUINTANA, 2002). This effectively ruled out MDC presidential candidate and veteran trade union leader Morgan Tsvangirai and represented a pre-emptory military coup in which Zimbabwe's security force chiefs warned voters that they would not accept an election result that removed ZANU-PF from office. Subsequently, ZDF senior officers repeated similar statements such as when ZDF Commander General Constantine Chiwenga, who later led the 2017 coup and then became vice president, proclaimed in the run-up to the 2008 presidential election that he would not tolerate "sellout and agents of the West" which referred to the MDC (HOPE AND FEAR, 2008).

With the creation of a temporary unity government after widespread election violence by ZANU-PF supporters in 2008, Zimbabwe's security force chiefs initially refused to salute newly appointed Prime Minister Tsvangirai, reserving this symbol of respect for President Mugabe (ZIMBABWE..., 2009). Such pronouncements from military leaders continued even after the 2013 constitution formalized the concept of apolitical armed forces. For instance, in September 2015, Brigadier General Anselem Sanyatwe, commanding officer of Zimbabwe's Presidential Guard, told his subordinates to "abandon professionalism" and threatened to use military force against former vice president Joyce Mujuru who had recently defected from the ruling ZANU-PF to form a new opposition party (SANYATWE..., 2015).

Several well-known reasons explain why Zimbabwe's military commanders wished to keep ZANU-PF in power during the crisis of the 2000 s and 2010s. Like other officials within Zimbabwe's government and security forces, Zvinavashe and Shiri were veterans of the liberation war when they had been members of ZANU-PF's military wing and as such had a long history within that organization. Another important factor was that the power and wealth of Zimbabwe's military elite was (and still is) tied to ZANU-PF remaining in office. From the early 2000s, security force commanders personally profited from Zimbabwe's chaotic land redistribution program that violently dispossessed the country's white commercial farmers and created an economic catastrophe from which it has never recovered. Along the same lines, Zimbabwean senior officers 
and politicians engaged in illegal diamond smuggling from the Democratic Republic of Congo (DRC) where the ZDF deployed from 1998 to 2002. Furthermore, and as discussed below, Shiri and others in the ZDF had directed atrocities in the southwest of Zimbabwe in the 1980s and were likely worried about potential prosecution should the regime fall.

During the 2000s, the Zimbabwean state militarized with retired ZDF officers given important positions within the government, ruling party, and civil service. At the same time, rank-and-file soldiers who questioned the politicization of the ZDF or expressed sympathy for the political opposition experienced victimization within the military prompting some to desert and join many other Zimbabweans escaping oppression and economic collapse by fleeing to neighboring countries (MARINGIRA, 2017a, 2017b, 2019). However, the process of turning the country's military into a wing of ZANU-PF began several decades before the Zimbabwe crisis of the 2000s and 2010s. This paper traces the politicization of the ZDF to its 1980 creation as an amalgamation of different combatant factions at the end of the country's liberation war and during the force's initial operations of the 1980s and early 1990s. In examining this process, this paper utilizes archival files authored by British officials and military officers involved in advising on the early development of the ZDF and which represent some of the only accessible documentary primary sources on the topic.

\section{Post-colonial African Militaries}

When African countries gained independence from European colonial rule mostly in the 1960s, they often struggled with questions over what sort of national military structure to establish. In most cases, locally recruited colonial military formations transformed into national defense forces seen as an essential element of an independent nation state. While colonial militaries in Africa appeared to operate as Western-style professional and apolitical forces, they were racially hierarchical, recruited from specific African ethnic groups with imagined martial reputations, and were primarily intended to ensure internal security rather than defend against external threats. As such, they were inherently political instruments (ECHENBERG, 1991; PARSONS, 1999). In some 
newly formed independent African states of the 1960s, several politicians questioned the need to maintain a military at all. In decolonization era Nigeria, the Action Group, a political party popular in the western region where people had less attachment to the late colonial army, suggested that the country did not need a national military but were overruled by nationalists who wanted Nigerian armed forces to serve as a symbol of independence (MINERS, 1971; PETERS, 1997). Upon gaining its independence in 1966, impoverished Botswana could not afford to establish a military and there was no local British colonial army to comprise a nucleus. As a result, Botswana did not have a military until 1977, when regional conflicts created a need for the country to defend itself and diamond-mining revenues provided the means to do so. Subsequently, and with assistance from Britain and India, the Botswana Defence Force (BDF) developed along westernstyle apolitical military lines, never engaging in coups or mutiny (HENK, 2007; MOCHEREGWA, 2021).

In the wake of a 1964 army mutiny in the newly independent former British colonies of East Africa, Kenya stuck with a professional and apolitical military model sponsored by Britain while Tanzania abandoned colonial traditions and developed the highly politicized Tanzania People's Defence Force (TPDF) within a socialist one-party state (PARSONS, 2003; KILFORD, 2010; THOMAS, 2013). Tanzania was not an isolated case. Influenced by revolutionary socialism, several new African governments formed militaries that were part of a ruling party structure and seen as a people's militia that would not only defend their countries but also engage in economic production and national development. Given Guinea's abrupt break from France in 1958, Sekou Toure's Guinea Democratic Party (PDG) politicized the Guinean military seen increasingly as an organization of "militants in uniform" who assisted with civic projects such as construction, manufacturing, and farming. The legacy of the liberation wars of the 1960s and 1970s, in which the Soviet Union and communist China influenced the direction of African military culture within a Cold War context informed the shape of several post-colonial African militaries. When war-weary Portugal suddenly withdrew from its African territories in 1974, the armed African nationalist movements that had been fighting for independence for over a decade 
took power and transformed themselves into the governments and state militaries of Angola, Mozambique and Guinea-Bissau. In these instances, the ruling party and the military were one and the same (NELSON et al., 1975; BRYDEN; N'DIAYE, 2011; WEIGERT, 2011).

\section{Zimbabwe's Independence War (1965-80)}

In 1965, the white minority government of Southern Rhodesia (now Zimbabwe), led by Prime Minister lan Smith, unilaterally declared independence from Britain to avoid engaging in political reforms that would lead to the granting of equal rights to the black majority. Consequently, the African nationalists of the Zimbabwe liberation movement embarked on an armed struggle in pursuit of majority rule and legitimate independence. However, in 1964 a disagreement over strategy resulted in the division of the exiled Zimbabwe nationalists with Joshua Nkomo leading the Zimbabwe African People's Union (ZAPU) and Ndabaningi Sithole and later Robert Mugabe leading the Zimbabwe African National Union (ZANU). These groups developed military wings with ZAPU forming the Zimbabwe People's Revolutionary Army (ZIPRA) and ZANU forming the Zimbabwe African National Liberation Army (ZANLA). The subsequent conflict comprised two distinct phases.

During the late 1960s, during the first phase of the war, both insurgent groups staged in newly independent Zambia attempted unsuccessfully to infiltrate fighters across the Zambezi River and into Rhodesia. The second phase began in the early 1970s when ZANLA moved to Mozambique. Allied with the Front for the Liberation of Mozambique (FRELIMO), they embroiled in a conflict to expel the colonial Portuguese and embarked on a guerrilla war in adjacent Rhodesia. The departure of Portugal from Africa 1974-75-which meant that FRELIMO took over the Mozambican state-enabled ZANLA to expand its operations from Mozambique and greatly escalate and expand the guerrilla war within Rhodesia. By the late 1970s, white-ruled Rhodesia had lost control of much of the countryside, was struggling with crippling international sanctions, and came under pressure from its primary ally, apartheid South Africa, to end the war. At the same time, the Zimbabwe liberation forces also received prompting 
from their host African governments to enter negotiations (MARTIN; JOHNSON, 1981; MOORCROFT; MCLAUGHLIN, 2008; RANGER; BHEBHE, 1995).

In 1979, after several failed attempts to reach a negotiated settlement, the British-sponsored Lancaster House talks produced an agreement that ended the war and resulted in universal suffrage and independence for Zimbabwe the following year. The deal included temporary concessions to the white minority comprising continued representation in parliament and a ban on state-imposed land reform for the first decade of independence. Although the Lancaster House agreement did not deal with the issue of creating a new military for independent Zimbabwe, it stipulated that ZIPRA and ZANLA insurgents would report to assembly areas throughout the country and Rhodesian state forces would return to their bases. In fact, during the Lancaster House talks ZAPU leader Nkomo repeatedly called for a discussion of the new military but representatives put this off, leaving it for the first elected government to deal with. Since Nkomo's group numbered fewer fighters who mostly originated from an ethnic minority, he was concerned that the larger ZANU/ZANLA would come to dominate whatever new state force emerged. Winning the subsequent elections, ZANU-PF (formerly ZANU) formed a government with Mugabe becoming the first prime minister of independent Zimbabwe in April 1980.

Consequently, the new ZANU-PF administration declared that it would create the new ZDF, consisting of the Zimbabwe National Army (ZNA) and AFZ, through integrating former Rhodesian, ZIPRA and ZANLA personnel. Responsible for military integration, the government superimposed a new Joint High Command $(\mathrm{JHC})$ over the existing command structure of the three former combatant elements. From the 65,000 total military personnel from all three factions, 35,000 would form the ZDF and 30,000 would be demobilized. Since the vast majority of all combatants came from land forces and the former insurgent groups did not possess much air power, white Rhodesian personnel initially dominated the AFZ where early integration was extremely slow (MARTIN; JOHNSON, 1981; MOORCROFT; MCLAUGHLIN, 2008; RANGER; BHEBHE, 1995). 


\section{The Combatants}

During Zimbabwe's liberation war of the 1970s, the main African nationalist forces developed along different lines. Sponsored by the Soviet Union, ZAPUZIPRA adopted a Leninist revolutionary strategy advocating a small, professional cadre of insurgents striking centers of power at a critical moment. As such, ZIPRA developed a conventional Soviet-style military brigade in Zambia meant to invade Rhodesia after the regime there weakened from guerrilla warfare and international economic sanctions. However, the natural obstacle of the Zambesi River, the border between Zambia and Rhodesia, with its scant crossings represented a major dilemma for this approach.

Within Rhodesia, ZIPRA was not interested in politicizing the rural peasants and focused on building support by relying on ZAPU's existing political networks. They directly engaged and often defeated Rhodesian state forces (RSF) and established liberated zones in rural areas. With their main staging areas in Zambia and eventually Botswana from the mid-1970s, ZIPRA recruited mostly from the Ndebele, Karanga and Sotho people of Rhodesia's southwestern Matabeleland region that was also Nkomo's home. Although the Ndebele represented the majority in their region, in national terms, they were a minority, which would later pose a problem for ZAPU in electoral politics (SIBANDA, 2005).

With military assistance from the People's Republic of China, ZANLA adopted a Maoist approach to revolutionary warfare that emphasized politicizing the rural masses and fighting a guerrilla conflict meant to lead to an eventual seizure of Rhodesia's centers of power. Throughout the 1970s, ZANLA worried less about fighting Rhodesian security forces and more about using a combination of persuasion and coercion to gain support from the African peasantry. Among the most popular methods of political indoctrination was an all-night meeting called pungwe in which insurgents led rural people in revolutionary songs and statements, and denunciation of alleged traitors.

Throughout the 1970s, ZANLA expected villagers to provide food, information and recruits or face reprisals. In addition, ZANLA tried to identify with rural people by emphasizing grievances over land and employing traditional Shona spirit mediums who had been prominent in the 1896-97 rebellion called 
the First Chimurenga (First Struggle for Independence). Seeking legitimacy through association with historic resistance, ZANLA portrayed itself as champion of the Second Chimurenga. ZANU and ZANLA worked closely together through the dare re chimurenga (council of the struggle) which was initially controlled by political leaders but became more militaryoriented in the early 1970s. ZANLA developed a highly organized structure and employed very small insurgent cells that, for security reasons, did not know about one another. Although ZANU and ZANLA promoted women's emancipation as a goal of the struggle, in practice female insurgents performed traditional women's jobs such as cooking and carrying supplies. During the 1970s, ZANLA leaders ruthlessly suppressed several mutinies led by disgruntled insurgents within their ranks. For instance, in late 1974 Thomas Nhari, a Soviet trained member of ZANLA's general staff, led a mutiny in Zambia and Mozambique by those disillusioned over lack of supplies and weapons and poor camp conditions. The suppression of this mutiny would form a strong memory within ZANU-ZANLA and serve as a warning to other would-be traitors.

The movement of ZANLA to Mozambique's Tete province in the early 1970 s facilitated guerrilla warfare as it was relatively easy for insurgents to infiltrate adjacent northeastern Rhodesia with its hilly and forested terrain. Once FRELIMO took over independent Mozambique in 1975, ZANLA extended its staging areas along Rhodesia's entire eastern border and dramatically expanded its insurgency within that half of the country. As such, ZANLA took on an increasingly Shona ethnic character as its recruits came mostly from eastern Rhodesia's Mashonaland region. During the late 1970s, the mostly Shona ZANLA insurgents began to advance into the predominantly Ndebele southwest region where they clashed with ZIPRA fighters. Since the Shona represent Zimbabwe's largest ethnic group, their support would serve ZANU-PF well in the 1979 elections (LAN, 1985; NHONGO-SIMBANEGAVI, 2000).

The Rhodesian army and air force originated from the British military and colonial tradition. Since colonization in the 1890s, military force in Rhodesia had been the almost exclusive domain of the white settler minority that were hesitant to arm members of the black majority who might rebel or use military 
service to claim citizenship rights. Given the small white population, the Rhodesian colonial state formed white-led, primarily black infantry battalions during the world wars but then quickly disbanded them when hostilities ended. Southern Rhodesia's military expanded during the 1950s and early 1960s given its leading role in the British-sponsored Central African Federation that comprised a self-governing but short-lived British colonial regional power. During the guerrilla war period of the 1970s, the Rhodesian Army relied on conscription and regular call-ups from the small white minority, which caused manpower problems and hurt the economy already struggling from international sanctions. In the federal period, the Rhodesian army recruited full-time professional soldiers from both the white and black communities but the old white Rhodesian fear of arming blacks delayed the expansion of military recruitment among the black majority until the late 1970s by which time the war was lost. Furthermore, half-hearted reforms at the end of the 1970s produced the country's first black military officers, but they were very few and mostly career soldiers commissioned from the ranks and assigned administrative positions.

The Rhodesian Air Force packed a punch by African standards as it had inherited helicopters, jet fighters and jet bombers from Britain's defunct Central African Federation. It remained of mostly white formation. Though theoretically modelled on the British tradition of an apolitical and professional force, the Rhodesian military was highly politicized with white senior officers and exclusively white units like the Rhodesian Light Infantry (RLI) expressing strong political support for Smith's ruling Rhodesian Front Party. It appears that some white Rhodesian senior officers planned a coup called Operation Quartz to forestall the coming to power of an elected African government in 1980, but the anticipated order was never given. Additionally, toward the end of the conflict Rhodesian forces had created rural militias called "Security Force Auxiliaries" to pursue counterinsurgency on the cheap but these were disbanded in 1980 and not included in the ZDF integration (MOORCROFT; MCLAUGHLIN, 2008; WOOD, 2008; STAPLETON, 2011). 
Initially, several factors seemed to have had the potential of molding the ZDF into a Western-style apolitical military. In April 1980, by invitation of the new ZANU-PF government, a British Military Assistance and Training Team (BMATT) arrived in the country to help integrate the new ZNA. At the time, Prime Minister Mugabe assured the British that he wanted to rely solely on them to guide the creation of the new force. Beginning with 35 personnel, BMATT grew to a height of 167 in 1981 and continued working in a limited capacity until 2000 when relations between Zimbabwe and the UK deteriorated. In 1980 and 1981, the commander of BMATT regularly consulted with Mugabe enjoying more access to him than the British high commissioner. In 1980, BMATT orchestrated assessment and training programs for former ZIPRA and ZANLA insurgents, 450 from each group, identified by their respective organizations as potential officers and noncommissioned officers for the ZNA. BMATT instructors taught condensed courses for those selected as section, platoon, company, and battalion commanders. In July 1980, twelve officers, four from each of the three former combatant factions, travelled to Britain where they attended a short course on conventional military forces at Camberley. Other ZNA officers trained in Britain during the early 1980s. Although the British embodied the example of a Western apolitical force, BMATT remained pragmatic and sought to facilitate a military system that worked in the local context. The British influence also involved arms sales to Zimbabwe, as in 1981 Mugabe's government purchased eight British-made Hawk MK60 ground attack aircraft worth US\$45 million, followed by another five in 1992.

Given their experience working within a conventional military, former Rhodesian personnel initially did well in the new dispensation, and they often served as instructors for the early assessment and training courses. Indeed, former Rhodesian military commander Lieutenant General Peter Walls gained appointment as head of the JHC supervising the entire integration process (ALAO, 2012; CHITIYO; RUPIYA, 2005; KRIGER, 2003; WHITAKER, 2014). However, the racist legacy of white-ruled Rhodesia lingered with British advisors concerned that the "unbelievable insensitivity and stupidity of a number of ex-RSF personnel and instructors in word and deed at times towards ZANLA/ZIPRA trainees" endangered the process (ZIMBABWE, 1980). 
To augment limited British assistance and speed up the qualification of black Zimbabwean personnel, Mugabe called upon Nigeria, which was seen as a Pan-African ally that could provide training compatible with the British. Nigeria, which had experienced a series of military coups and regimes after independence, was then under a relatively short-lived civilian government (ABEGUNRIN, 2003). In May 1980, a Nigerian military delegation arrived in Zimbabwe, held discussions with ZANU-PF officials (not ZAPU ones) and interviewed candidates for military courses in Nigeria. Around 150 black Zimbabwean officer candidates, 100 for the army and 50 for the air force, went to the Nigerian Military Academy in Kaduna and then other training institutions. British diplomats who learned about this program in confidence from a Nigerian contact were not particularly pleased as they believed that "The Nigerian Armed Forces are not exactly Prussian in their efficiency and the type of training which they are likely to give to the Zimbabweans will not be of a particularly high quality" (MILITARY, 1980a).

It did not take long for Mugabe's government to move towards turning the ZDF into a politicized military loyal to the ruling ZANU-PF. During the war, many ZANLA leaders had received their foundational military training in China or Tanzania within the context of a revolutionary people's militia. Furthermore, the large number of ZANLA combatants, a result of their Maoist approach and recruiting from a majority ethnic group, meant that they would eventually dominant the new force. In late 1981, according to British sources, there were 5468 ZANLA and 3068 ZIPRA members awaiting integration into the state military. A British military advisor reported that "As predicted, ZIPRA are running out of men and the current battalions under induction are predominantly ZANLA, one of the three being exclusively so" (NORTH, 1981).

An early change in military leadership became significant. The June 1980 resignation of the frustrated Walls, who Mugabe refused to promote to full general, prompted a fast exodus of white former Rhodesian personnel from the ZDF and were replaced by black ex-insurgents whose training programs accelerated. At the top, ZANLA's Lieutenant General Rex Nhongo (Solomon Mujuru) became head of the ZDF with ZIPRA's Lookout Masuku as his deputy. 
British officials, who had discussed the possibility of seconding a British general to command the ZDF with Mugabe, considered Nhongo's appointment as "disastrous for white morale and for the amalgamation exercise" (MILITARY, 1980b).

The state created new military formations loyal to ZANU-PF. In February 1981, Mugabe, impelled by a failed assassination attempt, created a Presidential Guard modelled on an army unit to protect the regime's leadership. In this, Mugabe followed a predictable pattern as many post-colonial African leaders founded Presidential Guard units to counter potential coups and they generally led to praetorianism and division within the overall armed forces. The Zimbabwe Presidential Guard began as a battalion but eventually expanded to brigade size therefore representing a significant force within the military structure. At public ceremonials, Presidential Guard troops marched behind a soldier holding an official portrait of Mugabe. Furthermore, Mugabe's October 1981 visit to North Korea, which had supported ZANU during the 1970s liberation war, resulted in that dictatorship dispatching a 106-strong military team to Zimbabwe where they trained the ZNA's new 5 Brigade the subsequent activities of which are discussed below. North Korea provided weapons, artillery and armored vehicles for the brigade, which would possess more support elements than the other ZNA brigades while the Zimbabwe government paid the salaries of the North Korean instructors who received inflated ranks to earn more hard currency. When British and American diplomats tried to dissuade Mugabe from accepting North Korean military assistance and warned that it might jeopardize a $\$ 250$ million aid package from the United States, the prime minister claimed that it was important for his government to demonstrate non-aligned status in the Cold War context.

The 1981 rebellion of former ZIPRA combatants in Bulawayo, explained below, also likely informed Mugabe's decision. The training of 5 Brigade was conducted at Inyanga in the ZANU-PF heartland of eastern Zimbabwe and the formation consisted almost entirely of ZANLA veterans, which although contrary to popular opinion did have a very few former ZIPRA members. Under North Korean tutelage and reminiscent of ZANLA activities during the war, all 5 Brigade personnel received six hours of political instruction conducted by political 
commissars each week and all officers undertook another three hours of such training on Saturday mornings. A British report on 5 Brigade stated that "Political training emphasis was on loyalty to the 'Party,' the state, and above all the Prime Minister. Much of the time was spent learning and chanting political slogans"(NORTH, 1982a; SECRET, 1981). During celebrations on the second anniversary of independence in 1982, 5 Brigade made its first public appearance in which 200 soldiers put on a display of martial arts and held up a banner proclaiming “Let Us Lay Down Our Lives for Comrade R.G. Mugabe” (JOHNS, 1982). 5 Brigade comprised a ZNA unit but also an inherent part of the ruling party.

In 1981, ZANU-PF announced that it would establish military-style youth training camps, which would also engage in educational and agricultural activities in rural areas with instructors provided by the military. North Korean instructors were involved in the initial stages of the program. In June 1982, the Zimbabwe People's Militia (ZPM) formed as a part-time adjunct to the ZDF engaging in internal security and serving as a first line of defense against foreign incursion. In practice, the ZPM functioned as a ZANU-PF paramilitary and focused on quelling political opposition, particularly by ZAPU. The dissident issue in Matabeleland and the ZDF operations in Mozambique (see below) prompted the expansion of the ZPM to around 20,000 members by the mid-1980s (CHITIYO; RUPIYA, 2005; HENSHAW, 1981). Just as the state demobilized former insurgents not included in the ZDF, it mobilized a politicized part-time army in rural areas. A secret British report warned, "The introduction of a largely ZANU-PF militia together with the other new force may partially negate the effect of the ZNA demobilization program" (NORTH, 1982b).

Attempts by apartheid South Africa to destabilize neighboring Zimbabwe as a way to undermine Harare's support for the exiled anti-apartheid movement became important in inciting the politicization of the ZDF. As covered in the next section, a covert South African program attempted to exploit problems in Zimbabwe's military integration process. Another South African operation involved the AFZ. In July 1982, South African agents bombed Zimbabwe's newly delivered British-made Hawk aircraft at Gweru's Thornhill air base. In turn, six white AFZ officers, including deputy commander Air Vice Marshal Hugh Slatter, 
were arrested and tortured until they confessed to involvement in the plot. Immediately after a civilian court dismissed the charges against them, Zimbabwe state authorities re-arrested the six air force officers who spent another year in detention before their deportation (PETTER-BOWYER, 2005; TORTURE..., 1983).

The sabotage incident incited a rapid Africanization of the AFZ with temporary personnel imported from Pakistan, China, Nigeria, Tanzania and Zambia. In July 1983, the last white AFZ commander Air Marshal Norman Walsh resigned and was replaced by Pakistani Air Marshal Azim Daudpota. Former ZANLA senior army officers transferred to the air force including the ZNA's Major General Josiah Tungamirai, who became an air vice marshal, qualified as a pilot, studied at university, and took over as head of the AFZ in 1986 (CHITIYO; RUPIYA, 2005; ALAO, 2012).

By 1986, the ZDF consisted of the ZNA with 46,000 soldiers and the AFZ with 4,000 personnel. The army included six infantry brigades and support elements. It also comprised the presidential guard, a parachute battalion, a commando battalion, and a mechanized battalion. While former insurgents, mostly from ZANLA, dominated the leadership and rank-and-file, the recruitment of new soldiers who had not fought in the liberation war and who possessed higher educational levels introduced some divisions in the late 1980s (CHITIYO; RUPIYA, 2005; MARINGIRA, 2017a, 2017b).

\section{Post-Independence Violence and Military Politicization}

In February 1981, ZIPRA veterans at Entumbane in Bulawayo rebelled over delays in the military integration process, poor living conditions in their camp and favouritism towards former ZANLA fighters affiliated with the ZANU-PF administration. There were also disturbing rumours that former ZIPRA insurgents mysteriously disappeared once they integrated into the ZDF. The only formations capable of mounting operations at this early stage in the amalgamation process were former Rhodesian police and military units, who crushed the rebellion (WHITE, 2007). With the discovery of arms caches in southwestern Matabeleland in early 1982, ZAPU-ZIPRA, leaders were arrested and charged with treason, such as Masuku, or fled the country such as Nkomo. Some ZIPRA veterans deserted 
the ZNA or their integration camps and took to the bush as dissidents who resumed their war by targeting state officials and foreign tourists. Seeking to undermine the new African majority government in Zimbabwe, South Africa attempted to take advantage of the dissident problem by forming a counterrevolutionary group called Super-ZAPU in Matabeleland that failed to attract much support from politically mature ZAPU veterans.

In the midst of this scenario, South African involvement inspired paranoia within Mugabe's administration keenly aware of similar and more successful efforts to destabilize the FRELIMO state in Mozambique. In turn, Mugabe dispatched the North Korean trained and 3,500-strong 5 Brigade commanded by Perence Shiri who would later head the AFZ to Matabeleland to suppress the dissidents. Composed almost entirely of former ZANLA fighters who were Shona people from eastern Zimbabwe, 5 Brigade's motto was the Shona phrase Gukurahundi meaning "the rain that washes away the rubbish" and it was very likely that the rural Ndebele people came to think this referred to them. Between 1983 and 1987, 5 Brigade imposed a reign of terror on rural Matabeleland and parts of Midlands province that claimed some 20,000 lives. Local Ndebele and Kalanga people were forced to participate in all night "pungwes" where they sung Shona songs praising ZANU-PF, their crops and houses were destroyed, they were subjected to curfew and collective punishment which were tactics copied from the Rhodesian counter-insurgency campaign, and became victims of public beatings and summary executions. It should be noted that 5 Brigade was not the only ZDF unit deployed against ZAPU dissidents in Matabeleland and, as such, these operations contributed to the entire military becoming Mugabe's political instrument. The violence ended with the December 1987 Unity Accord in which ZAPU leaders such as Nkomo agreed to the absorption of their organization into ZANU-PF and they received rewards in the form of senior government positions under Mugabe who became an executive president (CATHOLIC, 1999). At this point Zimbabwe arguably became a de facto one-party state with only small and ineffective opposition parties functioning until the end of the 1990s and the rise of the MDC (ALEXANDER, MCGREGOR; RANGER, 2000; SIBANDA, 2005). 
Throughout the 1980s, Zimbabwe became involved in a counter-insurgency war in Mozambique. In October 1981, Zimbabwe's ZANU-PF government and Mozambique's FRELIMO government, which shared a long history of cooperation predating the independence of both countries, signed a security pact against South African destabilization of the region's black ruled states. Consequently, in 1982, an initial contingent of 600 Zimbabwean troops deployed to Mozambique to counter the South African sponsored Mozambique National Resistance (RENAMO) rebels who were sabotaging the country to undermine its support for anti-apartheid forces and the development of economic independence from Pretoria.

The ZDF deployment to Mozambique in the early 1980s partly represented an effort by Harare to take a leading role in the Front Line States comprising a regional grouping opposed to apartheid South Africa. In addition, RENAMO threatened the transport corridor from Mozambique's port of Beira to Zimbabwe's eastern border town of Mutare through which Harare's imported oil arrived without going through South Africa. In 1984, RENAMO destabilization pressured Mozambique into signing the Nkomati Accord in which it agreed to expel South African anti-apartheid activists and Pretoria promised to halt sponsorship of RENAMO. In June 1985, the leaders of both Zimbabwe and Tanzania undertook to support Mozambique against RENAMO. As such, Zimbabwe's military efforts expanded from safeguarding the Beira Corridor to include search and destroy operations against RENAMO. In August, Zimbabwean forces captured a large RENAMO base and discovered evidence of continued South African support that was supposed to have ceased. Furthermore, Zimbabwe, Mozambique and Malawi entered into a joint security agreement in 1985 that resulted in Zimbabwean troops securing the main road through Mozambique's Tete province, and particularly the town of Tete with its bridge across the Zambezi River plagued by RENAMO attacks.

At this time Zimbabwe and Mozambique came close to conflict with Malawi, under the conservative dictatorship of Dr. Hastings Kamuzu Banda, which was playing a double game as it harboured RENAMO rebels and acted as a conduit for their South African support. In 1986 and 1987, Zimbabwean, Tanzanian 
and Mozambican forces thwarted a major RENAMO offensive. Around the same time, Zimbabwe began to host training courses for Mozambican soldiers who received instruction from BMATT personnel. In 1987 Zimbabwean, Tanzanian and Mozambican troops seized five towns in northern Mozambique from RENAMO that began to shift its activities to the south.

By 1988, 15,000 Zimbabwe personnel operated in Mozambique and in 1990 eight Zimbabwean battalions protected road and rail links. While Zimbabwean military personnel in Mozambique engaged in smuggling and other illegal trade practises to compensate for economic problems at home, the Mugabe government declared that its heroic forces were fighting apartheid-sponsored bandits. Within Zimbabwe, the Mozambique deployment became unpopular by the late 1980s with criticisms, including from within ZANU-PF, about cost, casualties and army corruption, and revenge attacks carried out by RENAMO across the border. The ZDF eventually withdrew from Mozambique in 1993 given that political change in South Africa and the end of the Cold War prompted negotiations between FRELIMO and RENAMO. It is, however, very likely that this decade of close wartime cooperation with the officially politicized Mozambican and Tanzanian militaries furthered the growth of a similar institutional culture within the ZDF (CHITIYO, 2003; CHITIYO; RUPIYA, 2005; EMERSON, 2014).

\section{Conclusion}

The creation and evolution of the ZDF represents a useful case study of the now common practice, particularly in Africa, of integrating formerly hostile armed groups into a single national defense force within the context of a peacebuilding process. Such practices were rare when, in the early 1980s, the ZDF formed as an amalgamation of Rhodesian states forces, and the former insurgents of ZAPU-ZIPRA and ZANU-ZANLA. In a short time, however, the ZANUPF government and associated veterans of ZANLA dominated Zimbabwe's new military. In the late 1980s, observers noted that the ZDF presented a veneer of professionalism that concealed deeper politicization and praetorianism (YOUNG, 1997). In essence, the ZDF looked much like the British Army but it acted like the politicized militaries of Tanzania, Mozambique and Angola. In retrospect, this 
situation should not have been surprising. The Rhodesian military, which formed the early nucleus of the new force, was not as apolitical as it pretended to be and British advisors who assisted with the transition of the early 1980s were not entirely committed to forging a professional force.

Since the Lancaster House agreement contained no specifications on the composition and character of Zimbabwe's military, the new ZDF became vulnerable to manipulation and control by an increasingly authoritarian and politically powerful ZANU-PF government. This took place in an atmosphere of intense paranoia over security given South African-sponsored sabotage and insurgency throughout the region. With the quick departure of former Rhodesian officers and the forced removal of many former ZIPRA personnel from the ZDF in the early 1980s, it became easy and desirable to replace them from among the large number of former ZANLA fighters loyal to the ruling ZANU-PF.

The politicized character of the ZDF was further influenced by its operations in Matabeleland where it crushed Mugabe's political rival (ZAPU) and the long military campaign in Mozambique where it worked alongside overtly politicized allied forces from neighboring one-party states (Mozambique and Tanzania). Military officers were not just politically loyal to the Mugabe regime but as the economy declined and eventually collapsed in the late 1990s and 2000s, government contacts became central to personal enrichment and postretirement careers.

Therefore, and despite the rhetoric of the 2013 constitution, the heavily politicized character of the ZDF continues to entrench the ZANU-PF authoritarian administration though now under a new president and represents a major obstacle to democracy in contemporary Zimbabwe. Though military politicization became extremely apparent during the political and economic crisis of the 2000s, this situation originated in the 1980s with a flawed amalgamation process and the early deployments of the ZDF. 


\section{References}

ABEGUNRIN, Olayiwola. Nigerian foreign policy under military rule, 1966-1999. Westport: Praeger, 2003.

ALAO, Abiodun. Mugabe and the politics of security in Zimbabwe. Kingston: McGill-Queens University Press, 2012.

ALEXANDER, Jocelyn; MCGREGOR, JoAnn.; RANGER, Terence. Violence and memory: one hundred years in the "Dark Forests" of Matabeleland. Portsmouth: Heinemann2000.

BAYNHAM, Simon. The military and politics in Nkrumah's Ghana. Boulder: Westview Press, 1988.

BRYDEN, Alan.; N'DIAYE, Boubacar (eds), Security sector governance in francophone West Africa: realities and opportunities. [Geneva]: Geneva Centre for Democratic Control of Armed Forces, 2011.

CATHOLIC Commission for Peace and Justice, Breaking the silence/building true peace: a report on the disturbances in Matabeleland and the Midlands, 1980-88. Harare: Legal Resources Foundation, 1999.

CHITIYO, Knox. The ZNA in Mozambique, 1982-1991: the limits on pursuance of war as an extension of foreign policy. In: RANGER, Terence (ed.). The historical dimensions of democracy and human rights in Zimbabwe. [Harare]: University of Zimbabwe Publications, 2003. v. 2. p. 101-112.

CHITIYO, Knox.; RUPIYA, Martin. Tracking Zimbabwe's political history: the Zimbabwe defence force from 1980 to 2005. In: RUPIYA, Martin (ed.). Evolutions and revolutions: a contemporary History of militaries in Southern Africa. [Pretoria]: Institute for Security Studies, 2005. p. 338-352.

DECALO, Samuel. Coups and army rule in Africa: studies in military style. New Haven, CT: Yale University Press, 1976.

ECHENBERG, Myron, Colonial conscripts: the tirailleurs sénégalais in French West Africa, 1857-1960. Portsmouth, NH: Heinemann, 1991. 
HENK, Dan. The Botswana defence force in the struggle for an african environment. Basingstoke, UK: Palgrave-MacMillan, 2007.

HOPE and fear for Zimbabwe vote. New York Times, 26 Mar. 2008. Available in: https://www.nytimes.com/2008/03/26/world/africa/26zimbabwe.html. Access on: 26 Apr. 2021.

KILFORD, Christopher. The other Cold War: Canada's military assistance to the developing world. Kingston: Canadian Defence Academy Press, 2010.

KRIGER, Norma. Guerrilla veterans in post-war Zimbabwe: symbolic and violent politics. [Cambridge]: Cambridge University Press, 2003.

LAN, David. Guns and rain: guerrillas and spirit mediums in Zimbabwe. London: James Currey, 1985.

MARINGIRA, Godfrey, Politicization and Resistance in the Zimbabwean National Army, African affairs, London, v. 116, Issue 462, p. 18-38, Jan. 2017 a.

MARINGIRA, Godfrey. Politics, Privileges and loyalty in the Zimbabwe national army. African Studies review, [s.l.], v. 60, n. 2, p. 93-113, Sept. 2017b.

MARINGIRA, Godfrey. Soldiers and the state in Zimbabwe. London: Routledge, 2019.

MARTIN, David.; JOHNSON, Phyllis. The struggle for Zimbabwe. New York: Monthly Review, 1981.

MINERS, Norman. The nigerian army 1956-66. London: Methuen, 1971.

MOCHEREGWA, Bafumiki. 'Thebe ya Sechaba': a history of the Botswana defence force, c. 1977 - 2007. 2021. Thesis (Doctoral in Philosophy) - University of Calgary, Calgary, 2021.

MOORCROFT, Paul.; MCLAUGHLIN, Peter. The Rhodesian War: a military history. London: Pen and Sword, 2008. 
MILITARY assistance to Zimbabwe: Brigader I.A. Bako, report of military delegation to Zimbabwe, Nigerian Ministry of Defence, Lagos, 18 June 1980; D. Slater to A.C.D.S. MacRae. [S.l.]: National Archives (UK), 29 July 1980a. FCO $36 / 2807$.

MILITARY assistance to Zimbabwe: secret telegram. [S.l.]: National Archives (UK), 15 July 1980b. FCO 36/2807.

NORTH Korean military assistance to Zimbabwe: colonel C.L.G. Henshaw, Salisbury to major P.M.K. MacKellar, ministry of defense, London. [S.l.]: National Archives (UK), 11 Sept. 1981. FCO 106/464.

SECRET telegram. [S.l.]: National Archives (UK), 17 July 1981. FCO 106/464.

NORTH korean military assistance to Zimbabwe: colonel C.W. Ivey, Salisbury to colonel P.I.B. Stevenson, London: reports on 5 brigade. [S.l.]: National Archives (UK), 6 Sept. 1982a. FCO 106/780.

NORTH Korean military assistance to Zimbabwe: the "other new force" was 5 brigade. 15 Nov. 1982b. FCO 106/780.

JOHNS, Bruce. Is this Red-trained Brigade Mugabe's Plan for a Marxist State? Sunday Express, [London], 25 Apr. 1982. FCO 106/780.

HENSHAW to MacKellar. [S.l.], 11 Sept. 1981. FCO 106/464.

NELSON, Harold; DOBERT, Margarita.; MCLAUGHLIN, James.; MARVIN, Barbara. and WHITAKER, Donald. Area handbook for Guinea. [S.l.] Foreign Area Studies, 1975.

NHONGO-SIMBANEGAVI, Josephine. For better or worse: Women and ZANLA in Zimbabwe's liberation struggle. Harare: Weaver Press, 2000.

PARSONS, Timothy. The 1964 army mutinies and the making of modern East Africa. Westport, CT: Praeger Publishers, 2003.

PARSONS, Timothy. The african rank-and-file: social implications of colonial military service in the king's african rifles, 1902-1964. Portsmouth, NH; Heinemann, 1999. 
PETERS, Jimi. The nigerian military and the State. London: I.B. Tauris, 1997.

PETTER-BOWYER, Peter. Winds of destruction: the autobiography of a rhodesian combat pilot. Johannesburg: 30 Degrees South, 2005.

QUINTANA, Michael. How loyal is Zimbabwe's army. BBC News, [London], 10 Jan. 2002. Available in: http://news.bbc.co.uk/2/hi/africa/1754063.stm. Access on: 26 Apr. 2021.

RANGER, Terence. and BHEBHE, Ngwabi. (eds.). Soldiers in Zimbabwe's liberation war. London: James Currey, 1995.

SANYATWE Under Fire Over Mujuru. Zimbabwe Independent, [s.l.] 16 Oct. 2015. Available in: http://www.theindependent.co.zw/2015/10/16/sanyatwe-under-fireover-mujuru/. Access on: 26 Apr. 2021.

STAPLETON, Timothy. African police and soldiers in colonial Zimbabwe, 19231980. Rochester: Rochester University Press, 2011.

SIBANDA, Eliakim. The Zimbabwe african people's union, 1961-1987.Trenton, NJ: Africa World Press, 2005.

SIOLLUN, Max. Oil, politics and violence: Nigeria's military coup culture, 1966-76. New York: Algora Publishing, 2009.

TORTURE is Key Element in Zimbabwe Trial of Six Airmen. New York Times, New York, 6 June 1983. Available in: https://www.nytimes.com/1983/06/06/world/torture-is-key-issue-inzimbabwe-trial-of-6-airmen.html. Access on: 26 Apr. 2021.

THOMAS, Charles. The Tanzanian people's defence force: an exercise in nation building. 2012. Thesis (Doctoral in Philosophy) - University of Texas, Austin, 2012.

WEIGERT, Stephen. Angola: a modern military history. Basingstoke, UK: PalgraveMacMillan, 2011.

WHITAKER, Blake. The 'new model' armies of Africa?: the british military advisory and training team and the creation of the Zimbabwe national army. 
2014. Thesis (Doctoral in Philosophy) - Texas A\&M University, College Station, 2014.

WHITE, Louise. Whoever saw a country with four armies? the battle of bulawayo revisited. Journal of Southern African Studies, [s.l.], v. 33, n. 2, p. 619631, Sept. 2007.

WOOD, J.R.T. Countering the Chimurenga: the Rhodesian counterinsurgency campaign 1962-80. In: MARSTON, D.; MALKASIAN, C. (eds.). Counterinsurgency in modern warfare. [Oxford]: Osprey Publishing, 2008. p. 185-202.

YOUNG, Eric.T. Chefs and worried Soldiers: authority and power in the Zimbabwe national army. Armed forces and society, [s.l.], v. 24, n. 1, p. 133-149, 1997).

ZIMBABWE military assistance: secret telegram. [S.l.]: National Archives (UK), 17 May 1980. FCO 36/2806.

ZIMBABWE military chiefs still won't salute premier. Nation, [S.l.], 26 July 2009. Available in: https://nation.africa/kenya/news/africa/zimbabwe-military-chiefsstill-won-t-salute-premier--600112. Access on: 26 Apr. 2021.

ZIMBABWE. Zimbabwe's Constitution of 2013. [Harare: National government], 2013. Section 221, p. 102. Available in:

https://www.constituteproject.org/constitution/Zimbabwe_2013.pdf. Access on: 26 Apr. 2021. 